温熱的生理心理反応の個人差に関する研究

一夏期における設定気温条件の場合一

\title{
EXPERIMENTAL STUDY ON INDIVIDUAL VARIATION OF THERMAL PHYSIOLOGICAL AND PSYCHOLOGICAL RESPONSE \\ - Cases of designed air temperature in summer-
}

\author{
佐 々尚 美*, 久保博子**, 磯田憲生***, 梁 瀬 度子**** \\ Naomi SASSA, Hiroko KUBO, Norio ISODA \\ and Takuko YANASE
}

\begin{abstract}
The study aims to investigate the individual difference of thermal physiological and psychological responses to various air temperature conditions in summer. Healthy 29 women were exposed to air temperature $\left(20^{\circ} \mathrm{C}, 24^{\circ} \mathrm{C}, 28^{\circ} \mathrm{C}\right.$ and $\left.32^{\circ} \mathrm{C}\right)$ during 120 minutes in a climate chamber.

The results were as follows ;

There were differences among individuals in skin temperature, especially peripheral parts of the body ,thermal comfort and thermal sensation. The subjects grouped into three based on preferred air temperature to investigate the responses in detail. Consequently, differences among three groups were found in thermal sensation, skin temperature distribution and skin temperature v.s.thermal comfort.
\end{abstract}

Keywords : Individual variations, Thermal comfort, Thermal sensation, Skin temperature, Heat loss 個人差、快適感、温冷感、皮膚温、放熱量

\section{1.はじめに}

室内の温熱環境の快適性についてはこれまで多くの研究がなされ ており、種々の推奨温度が提唱されている。しかし、ASHRAEでも 「全ての人が満足する環境は存在しない」iうとている様にその推 奖されている気温に室温が保たれていても、非常に快適と感じる人 ばかりでなく、不快と感じる人も存在している。これまで、 ASHRAEでは'Individual Variations ${ }^{2)}$ において、P.O.Fangerらによる PMVとPPDとの関係より不満足率を予測し何\%が不満かという手法 を示し、日本では深井ら (3) 4) は温度に対する反応性の違いを認め個 人差が大きいとし、江口ら ${ }^{\text {) }}$ は快適温の個人差について特徴を持っ た5群に分けることを試みているなど、個人差についての研究はあ るが、その個人差がどの程度あるのか、また何が要因で生じている かの詳細な記述は少ない。そこで、その個人差を考慮し、より多く の人が快適と感じる温熱環境を創造する為には、気温に対する生理 反応、心理反応に個人によりどの程度の反応差があるのかを把握 し、それらを生じさせる要因が快適と感じる気温の差にどの様に及 ぼすかを検討することが重要であり、その個人差を生じさせる要因 別に応じた温熱環境を作り出すことが、これからの課題であると考 えられる。これまで、筆者らは「ちょうど良い」と感じる様に自分 自身で自由に気温を調節する選択気温実験 ${ }^{6)}$ を行った結果、「涼し
い」〜「どちらでもない」と感じる様に気温を調節し、その気温は 被験者間において $7.2^{\circ} \mathrm{C}$ 差、平均皮膚温には $3.5^{\circ} \mathrm{C}$ 差が認められ るという結果を得ている。そこで本報告では、夏期において温熱環 境下における生理心理反応の個人差の把握を行うことを目的とし、 前述の選択気温実験と同じ被験者を用いて設定気温環境下に暴露し た場合の生理心理反応について検討を行った。

\section{2.実駼方法}

\section{$2-1$. 実験室}

実験には奈良女子大学人工気候室 $A$ 室（実験室）とB室（前室） 7)を用いた。図1に人工気候室の平面図を示す。また、両室とも周 囲壁面温度は気温とほぼ等しく設定され、0.1 $\mathrm{m} / \mathrm{s}$ 以下の不感気流 時でもほぼ設定温湿度に制御可能である。

\section{2-2.実験条件}

表1に実験条件を示す。前室の気温を $28^{\circ} \mathrm{C}$ と、実験室では、気 温を $20^{\circ} \mathrm{C} 、 24^{\circ} \mathrm{C} 、 28^{\circ} \mathrm{C} 、 32^{\circ} \mathrm{C}$ の段階に設定した。周囲壁面温度 は気温とほぼ等しいとし、不感気流、相対湿度 $50 \%$ 一定とした。 人体側条件として、被験者は全て既報の！「ちょうど良い」と感じ る様に自由に気温を被験者自身で調節する「選択気温実験」におい て採用した被験者と同じ健康な女子大学生29名を採用した。ま
* 奈良女子大学大学院人間文化研究科博上後期課程 大学院生・家修

** 奈良女子大学生活䍗境学部生活罢境学科 助教授・博士 (学術)

*** 奈良女子大学大学院人間文化研究科 教授・工博

**** 武庫川女子大学生活環境学部 教授・医博
Graduate School of Human Culture, Nara Women's University, M. Home Eco.

Assoc. Prof., Faculty of Human Life and Environment, Nara Women's University, Ph. D

Prof., Graduate School of Human Culture, Nara Women's University, Dr. Eng. Prof., School of Human Environmental Health, Mukogawa Women's University, Dr. Med. 
表1 実験条件

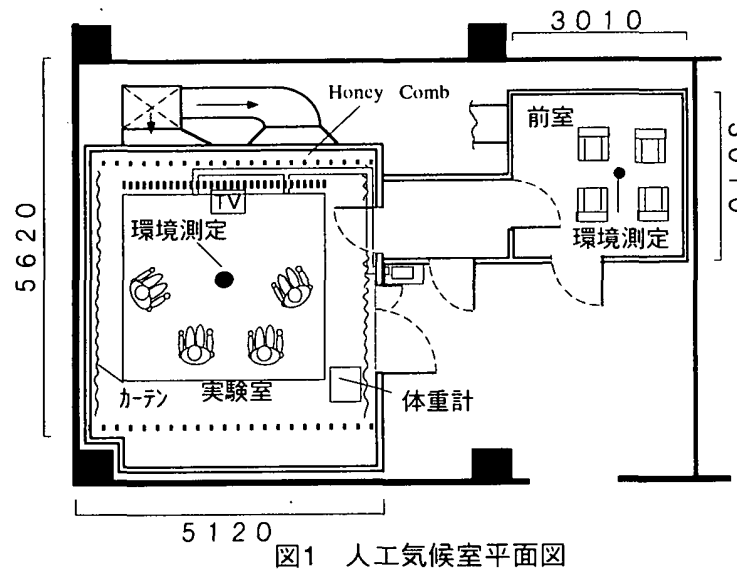

た、着衣量（Tシャツ、スカート、ストッキング、パンティ、ブラ ジャー) ( 0.3 clo $^{8) 9)}$ とした。表2に被験者の身体的特徵を前述の 選択気温実験6ににて得られた選択気温群別に示す。尚、低温群は選 択気温 $25^{\circ} \mathrm{C}$ 以下、中温群は選択気温 $25^{\circ} \mathrm{C} \sim 29^{\circ} \mathrm{C}$ 、高温群は選択気 温 $29^{\circ} \mathrm{C}$ 以上とした者である。体型体格は全国平均(1) と比較する と、ほぼ標準的な被験者であった。

\section{2-3.测定項目およひ测定方法}

(1) 测定項目

温熱環境要素として、室の中央にて気温の垂直分布、湿球温度、 黒球温度、気流速度を測定した。生理的反応として、皮虚温・舌下 温 - 体重減少量 - 心拍数 - 血压、心理的反応として、快適感 (SD 法 7段階）・温冷感（9段階）・室温評価などを測定した。また、 得られた測定値をSASを用い分散分析を行った。

(2) 測定方法

気温、気流速度、周囲壁面温度の測定を行った。気温は床上高さ $10 \mathrm{~cm} 、 60 \mathrm{~cm} 、 110 \mathrm{~cm}$ において、湿球温度と黒球温度は床上 $60 \mathrm{~cm}$ に おいて、0.1 mm $\phi$ の熱電対を用い多点温度計にて測定した。気流速 度は被験者の位置において熱線風速計を用いて測定した。皮䖉温は $0.1 \mathrm{~mm} \phi$ の熱電対をサージカルテープを用い、Hardy \& DuBoisによ る皮膚温 7点 ")に貼付し、多点温度計にて測定した。舌下温は婦人 体温計を用いて5分間測定した。体重減少量は体重計を用い実験開 始前と実験終了時の2回測定し、その差から算出した。申告は、紙 上の申告項目について被験者自身で記入してもらった。

\section{$2-4$. 実験手的}

実験手順を図 2 に示す。被験者は気温 $28^{\circ} \mathrm{C}$ に設定された人工気候 室に入室し、設定着衣を着用後、熱電対を貼付し、椅座安静を保ち 約 30 分間暴露した後、各条件に設定した人工気候室に入室し、120 分間暴露した。測定は皮虐温は 30 秒間隔、舌下温 - 申告は 10 分間 隔、心拍数 - 血圧は 30 分間隔、体重は実験室入室時と実験終了時 に測定した。実験は1995年7月14日〜8月5日にかけて行った。

\section{3.実験結果}

\section{3-1.温熱㻴境条件}

気温はほぼ設定気温士 $0.2^{\circ} \mathrm{C}$ 範囲に保つことが出来た。また相 対湿度は、ほぼ設定相対湿度 $50 \pm 0.5 \%$ に維持出来た。室内上下気

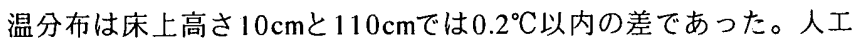
気候室内の被験者の近傍では $0.1 \mathrm{~m} / \mathrm{s}$ 以下の不感気流であった。

\section{3-2.皮届温およひ温椧感、快適感の経時変動例}

\section{(1)平均皮膚温の経時変動}

図3に平均皮䖉温の経時変動の一例として高温群のsub.A、中温 群のsub.B、低温群のsub.Cの測定結果を気温別に示した。設定気温

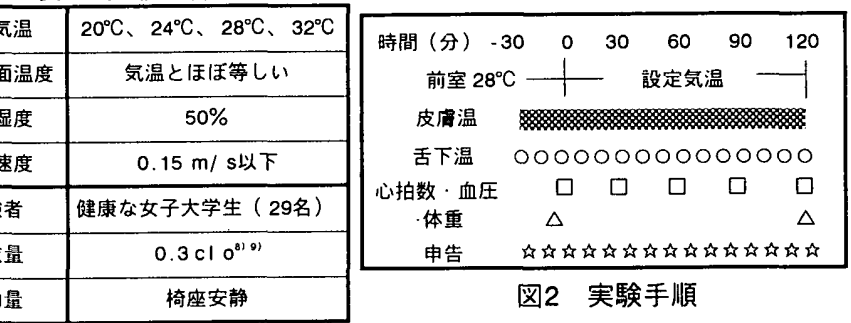

被験者の身体的特徵

\begin{tabular}{|c|c|c|c|c|c|c|}
\hline \multirow{2}{*}{\multicolumn{2}{|c|}{ 選択気温群 }} & 年鰙 & 身長 & 体重 & 体表面糟 & 体格指数 \\
\hline & & j & $\mathrm{cm}$ & $\mathrm{kg}$ & $\mathrm{m}^{2}$ & $\mathrm{~kg} / \mathrm{m}^{2}$ \\
\hline \multirow{2}{*}{$\begin{array}{l}\text { 高温群 } \\
(n=4)\end{array}$} & Avg & 19.75 & 158.00 & 50.19 & 1.50 & 20.11 \\
\hline & SD. & 1.30 & 3.09 & 2.79 & 0.04 & 1.12 \\
\hline \multirow{2}{*}{$\begin{array}{l}\text { 中温群 } \\
(n=20)\end{array}$} & Avg & 19.95 & 158.82 & 51.72 & 1.52 & 20.47 \\
\hline & SD. & 1.20 & 4.70 & 5.84 & 0.09 & 1.74 \\
\hline \multirow{2}{*}{$\begin{array}{l}\text { 低温群 } \\
(n=5)\end{array}$} & Avg & 21.00 & 156.82 & 49.85 & 1.48 & 20.31 \\
\hline & SD. & 0.89 & 2.66 & 7.85 & 0.09 & 3.37 \\
\hline \multirow{2}{*}{$\begin{array}{c}\text { 全員 } \\
(n=29)\end{array}$} & Avg & 20.10 & 158.36 & $51: 19$ & 1.51 & 20.39 \\
\hline & SD. & 1.26 & 4.36 & 6.09 & 0.09 & 2.09 \\
\hline 全国平均 ${ }^{10)}$ & Avg & 20) & 156.6 & 50.4 & 1.49 & 20.6 \\
\hline
\end{tabular}

体表面積( As )

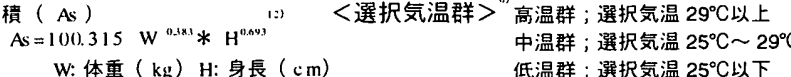

$20^{\circ} \mathrm{C}$ では、sub.Aは気温の影響を受け 120 分間徐々に低下し $31^{\circ} \mathrm{C} ま$ で低下した。sub.Cでは入室20分後以降はsub.Bとほほ同様に低下

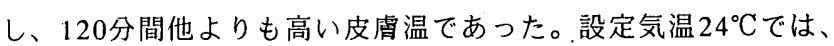
sub.Aは入室60分後まで徐々に皮䖉温は低下したが、以後安定して いた。一方、sub.Cはのわかに皮膚温は低下した。設定気温 $28^{\circ} \mathrm{C}$ では、sub.Aは多少の変動は認められるが、120分間ほぼ安定した が、sub.B・sub.Cは入室20分後まで緩やかに上昇し、以後安定し

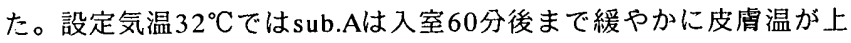
昇し、以後若干低下する傾向がみられたが、sub.B・sub.Cは若干変 動は認められるが、緩やかに上昇し続けた。

(2)温冷感の経時変動

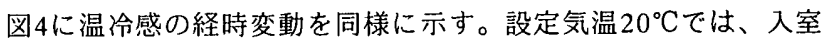
40分後までsub.C、 sub.B. sub.Aの順に一段階づつより寒い側の申 告で一定あったが、sub.Bは入室50分後に、sub.Cは110分後に一段

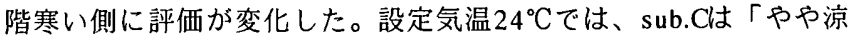
しい」、sub.Bは「涼しい」の申告でほぼ一定であったが、sub.Aは 「やや涼しい」〜「涼しい」の間を変動し、入室100分後以降は 「寒い」の申告で一定となり、各被験者間は1段階の申告差となっ

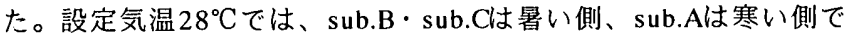

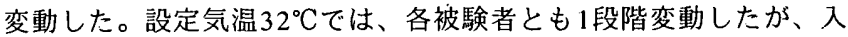
室60分後以降はsub.A、sub.B、sub.Cの順に一段階づつより屠い側 の申告でほぼ一定であった。

(3)快適感の経時変動

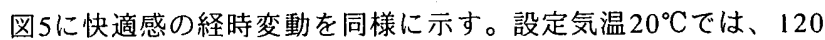
分間sub.Aは不快側、sub.Cは快適側の申告であったが、sub.Bは入 室40分後まで快適側の申告であったのが、不快倒に移動し、sub.A

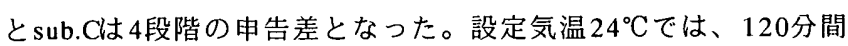
sub.Aはほぼ不快側、sub.B・sub.Cは快適側の申告であり、sub.Aと

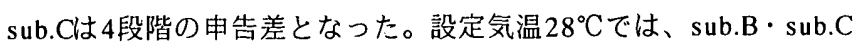
は120分間ほぼ「どちらでもない」の申告で一定であったが、 sub.Aは入室 60 分後以降快適感が增しほぼ「快適」の申告となっ

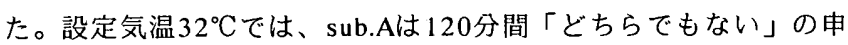
告であったが、sub.B・sub.Cは不快側であり、入室60分後以降不快 感が増し、sub.Aとsub.Cは3段階の申告差となった。 

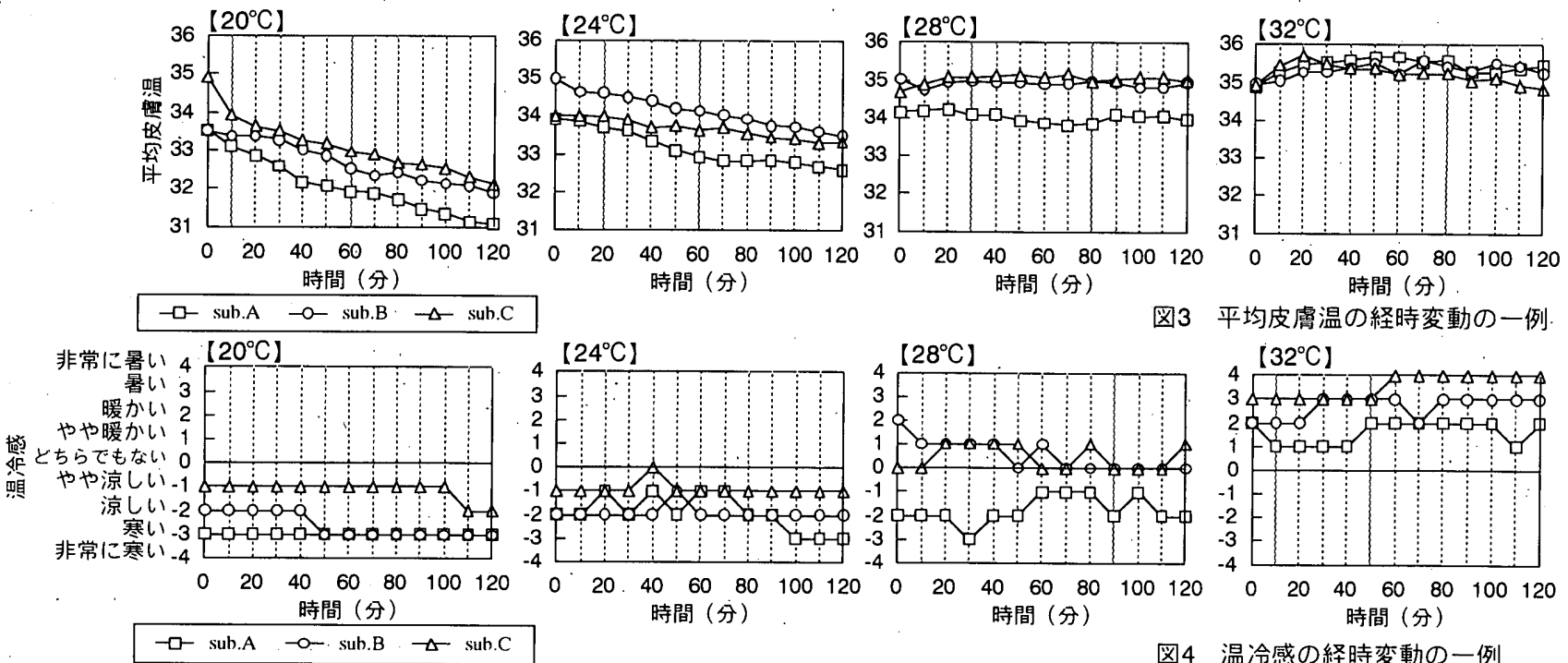

図3

時間 (分)

平均皮膚温の経時変動の一例.

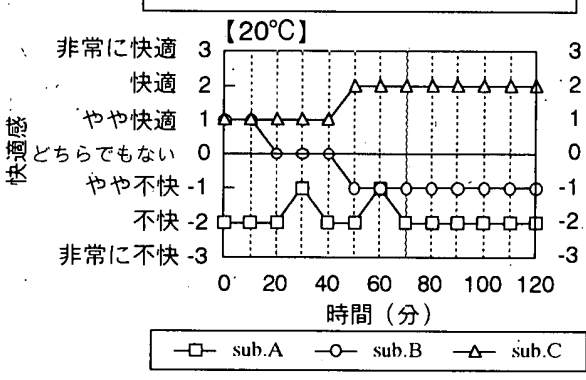

3-3.皮用温およひ温冷感、快適感の分布

(1)設定気温別の各部位別皮膚温の分布

図6に全被験者における各部位別皮虐温を設定気温別に平均値と 標準偏差で示す。設定気温の違いによる各部位皮膚温の平均值の差 は設定気温 $28^{\circ} \mathrm{C}$ と $32^{\circ} \mathrm{C}$ の腹部以外は有意に認女られ、特に足背が 最も大きく、設定気温 $20^{\circ} \mathrm{C}$ と $32^{\circ} \mathrm{C}$ における皮膚温には $10^{\circ} \mathrm{C}$ 差が 認められ、次いで、手背、腕、下腿の順に大きく見られた。また、 各設定気温別に部位別皮膚温を検討すると、設定気温 $28^{\circ} \mathrm{C} 、 32^{\circ} \mathrm{C}$ では、各部位別の皮膚温にはあまり差は認められなかったが、低温 になる程、皮膚温分布が大きくなり、気温が皮虙温に及ぼす影響の 違いが認められ、特に腕、手背、下腿、足背等の未梢部にかなり差 が認められた。低温になるにつれ各部位別の皮㲊温の標準偏差が大 きく、特に末梢部の皮覤温の標準偏差が大きかった。 (2)設定気温別の温冷感の分布

図7に設定気温別の温冷感の分布を申告人数と各設定気温別の平 均值士標準偏差で示す。また、球の直径は申告者数を示す。各設定 気温内では設定気温 $20^{\circ} \mathrm{C}$ と $24^{\circ} \mathrm{C}$ では、被験者により「-4: 非常に 寒い」あるいは「-3: 寒い」〜「0:どちらでもない」の約5段階の

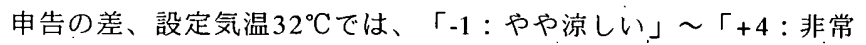
に暑い」の6段階の申告の差が認められ、標準偏差も大きかった。

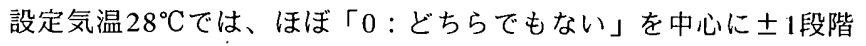
の違いであり、最も被験者による温冷感申告の差が小さかった。 (3)設定気温別の快適感の分布

図8に設定気温別の快適感の分布を同様に示す。各設定気温内で

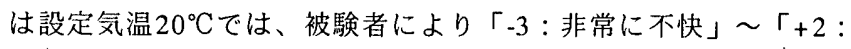
快適」の6段階の申告の差、次いで設定気温 $24^{\circ} \mathrm{C} て ゙ は 「-2:$ 不快」 $\sim\ulcorner+2:$ 快適」の 5 段階の申告の差であり、快適側から不快側まで 被験者により評価に差が認められ、標準偏差も大きかった。設定気

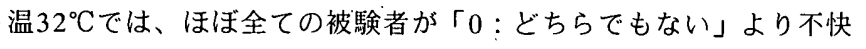

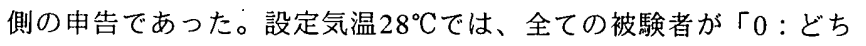
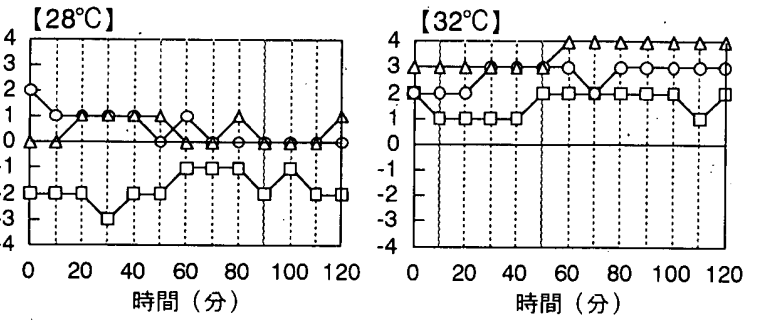

図4 温冷感の経時変動の一例
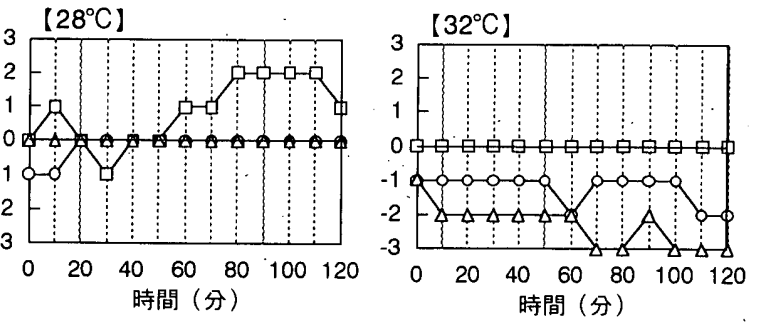

図5快適感の経時変動の一例

らでもない」より快適 側の申告であり、温冷 感申告と同様に快適感 申告の被験者による差 が最も小さかった。更 に、温冷感と快適感の 関係を検討すると、欧 米では Houghten と Yaglouによる「署くも 寒くもない状態」が快 適である(3) としている が、日本では夏期は 「涼しい」と感じる時 を快適とすると報告(1) があり、本結果も同様 であうた。これらの違

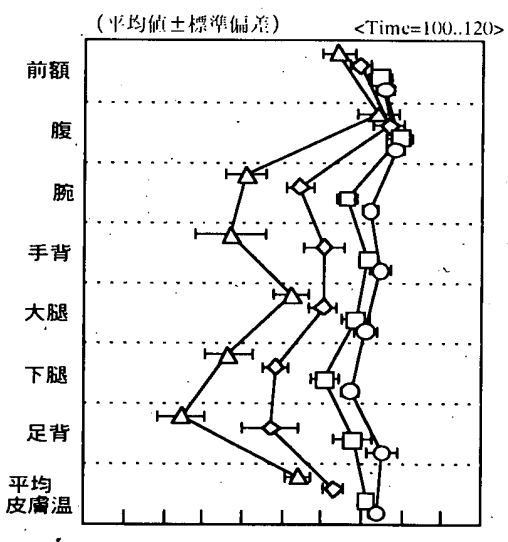

• 2022242628303234363840 皮居温 ( $\left.{ }^{\circ} \mathrm{C}\right)$
いは申告に用いた言語図6 設定気温別の各部位皮膚温別の分布 尺度の語感の影響が要因となっていると考えられる。

(4)温冷感申告別の平均皮膚温の分布

罒9に温冷感申告別の平均皮虐温の分布を示す。「0:どちらで もない」より「暖かい・暑い」側では、申告の違いによる平均皮虑 温の差も小さく、また温冷感が「+4:非常に暑い」になるにつ れ、同じ温冷感申告となる平均皮膚温の差が小さくなった。一方、 $\ulcorner 0:$ 「゙ち.らでもない」より「涼しい・寒い」側では、申告の違い による平均皮膚温の差が大きく、また、同じ温冷感となる平均皮盧 温にも差が大きく、特に「-2: 涼しい」と感じる平均皮膚温は 30.5 ${ }^{\circ} \mathrm{C} \sim 35.3^{\circ} \mathrm{C}$ 範囲、「-1：やや涼しい」では $31.2^{\circ} \mathrm{C} \sim 35.5^{\circ} \mathrm{C}$ の範囲 であり $4^{\circ} \mathrm{C} \sim 5^{\circ} \mathrm{C}$ 差が認められた。これらの事より、暑い側と寒 い側で平均皮虚温と温冷感申告との関係には違いが見られ、寒い側 で被験者による差が大きく示された。 


\section{4.考察}

健康な女子大学生を対象に行い、年齢、性別、体格、生活パ夕一 ン等を同一にして実験をしたにもかかわらず、低温において部位皮 膚温、特に末梢部の皮膚温の差が大きく、温冷感、快適感も5段階 から6段階異なり、また、寒い側の同じ温冷感となる平均皮膚温に も差がみられ、個人により生理心理反応には差が大きく認められ た。この個人差を考慮せずこのまま全体を平均化し、至適温度の提 案を行うのには問題があると考えられる。そこで、これらの個人差 をグループ別に検討する為に、住宅熱環境評価研究委員会による 58 年度住宅熱環境評価基準值 ${ }^{(5)}$ である $27^{\circ} \mathrm{C} \pm 2{ }^{\circ} \mathrm{C}$ と、既報() による 「ちょうど良い」と感じる様に被験者自身が自由に調節すると全員 の平均と標準偏差が $27^{\circ} \mathrm{C} \pm 2^{\circ} \mathrm{C}$ という結果より、前述と同様に気温 を $25^{\circ} \mathrm{C}$ 以下に調節した被験者を低温群、 $29^{\circ} \mathrm{C}$ 以上に調節した被験 者を高温群、 $25^{\circ} \mathrm{C} \sim 29^{\circ} \mathrm{C}$ 範团に調節した被験者を中温群として3 つの群に分けて検討した。

\section{(1)設定気温と平均皮凰温の関係}

図10に各設定気温における入室100～120分後の平均皮膚温を群 別の平均値土標準偏差で示す。3群とも気温が高いほど平均皮膚温 も高かった。また、平均値について群別に検討すると設定気温 20

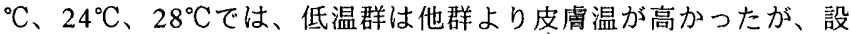
定気温 $24^{\circ} \mathrm{C}$ において各群の間に有意差が認められた。さらに、設 定気温 $20^{\circ} \mathrm{C}$ と設定気温 $32^{\circ} \mathrm{C}$ の群別の平均皮膚温の差は低温群は 3.4 ${ }^{\circ} \mathrm{C}$ 、中温群は $3.9^{\circ} \mathrm{C} 、$ 高温群は $4.1^{\circ} \mathrm{C}$ であり高温群において気温の違 いによる皮虑温への影響が最も大きかった。

(2)娮定気温別の部位別皮虐温の分布

図11に各設定気温における入室100～120分後の部位別皮膚温を 群別の平均值で示す。各設定気温ごとの部位の皮膚温の分布は3群 とも、躯幹部が高く、未梢部が低く分布していた。各群内の部位の 皮膚温差は設定気温 $20^{\circ} \mathrm{C}$ で差が $10^{\circ} \mathrm{C}$ と最も大きくなり、気温が高 くなると皮膚温差は小さくなった。また、群別に比較すると、設定 気温 $20^{\circ} \mathrm{C}$ では低温は手背の皮膚温は低いが、脚部は他群より約 0.7
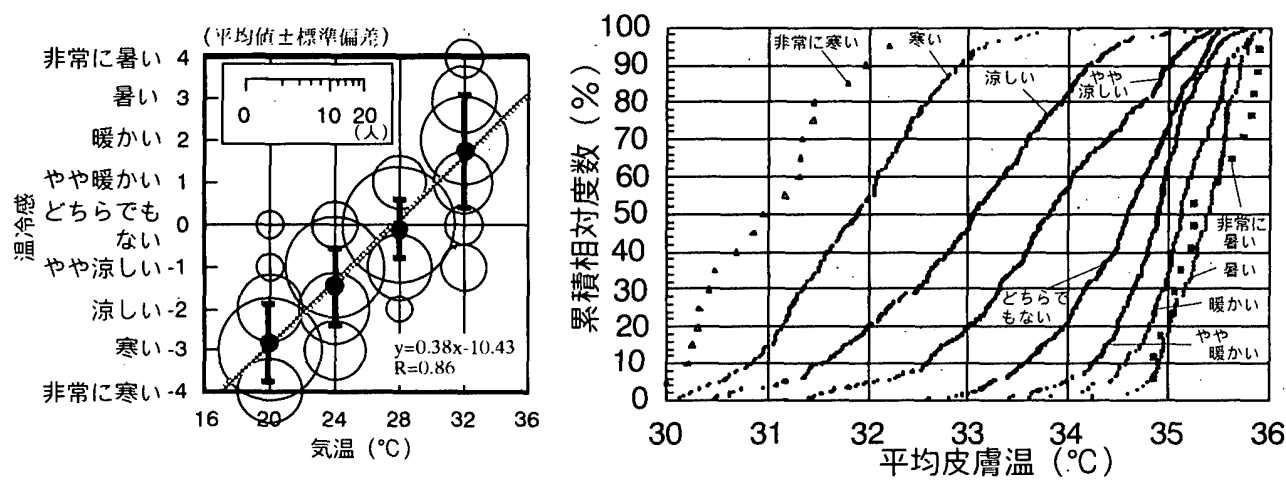

図7設定気温別の温冷感の分布

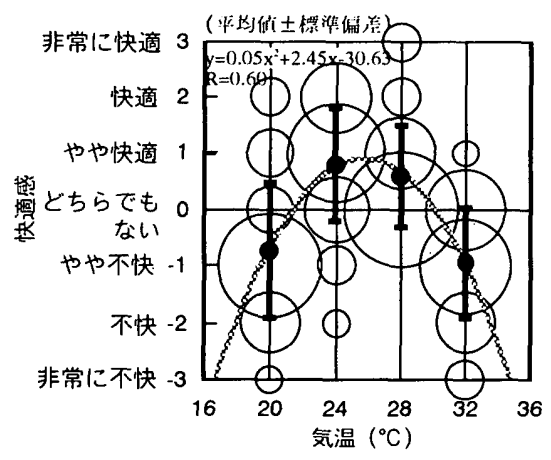

図8

設定気温別の快適感の分布 $\sim 1.3^{\circ} \mathrm{C}$ 高い皮膚温であった。平均皮唐温で各群間に有意差が認め

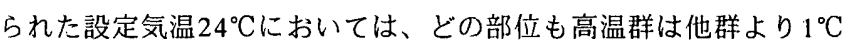
前後低い皮有温であった。設定気温 $28^{\circ} \mathrm{C} 、 32^{\circ} \mathrm{C}$ では3群ともほぼ同 じ皮膚温であったが、高温群の各部位の皮膚温は他群より高く、特 に手背、大腿、足背の未梢部などの皮虑温が他群よりも高くなって いた。有意な差は認められなかったが、低温群は設定気温 $20^{\circ} \mathrm{C}$ に おいて脚部の皮膚温が他群より下がらず、一方、高温群は特に手背 や足背などの未梢部の皮膚温が他群に比べ環境の影響を受けやす く、前述の58年度住宅熱環境評価基準値 ${ }^{(5)}$ の下限に近い設定気温 $24^{\circ} \mathrm{C}$ において他群より皮膚温が低くなるという特徽が認められ、 更に生理学的な面から検討する必要がある。

(3)設定気温と放熱量の関係

図12に設定気温別の「水分蒸発放熱量」17)「対流＋放射放熱量」 17) iE2)「総放熱量」を群別の平均値と標準偏差で示す。「水分蒸発 放熱量」は、設定気温が高い程多かった。各設定気温の群別の平均 値では設定気温が高い程群差が大きくなり、設定気温 $32^{\circ} \mathrm{C} て ゙ は$ は低 温群の方が高温群に比べ約 $8.6 \mathrm{w} / \mathrm{m}^{2}$ 多くなり、低温群は発汗調節領 域に入りつつあると考えられる。「対流+放射放熱量」は気温が高 い程少なく、設定気温 $24^{\circ} \mathrm{C}$ におて有意差が認められた。「総放 熱量」も気温が高い程少なく、「対流+放射放熱量」と同様の傾向 を示した。また、各設定気温別の群別の平均值では、設定気温 24 ${ }^{\circ} \mathrm{C} 、 24^{\circ} \mathrm{C} 、 32^{\circ} \mathrm{C}$ では約 $8 \mathrm{w} / \mathrm{m}^{2} \sim 10 \mathrm{w} / \mathrm{m}^{2}$ の群差が認められ、高温 群、中温群、低温群の順に放熱量が多くなる傾向にあり、設定気温

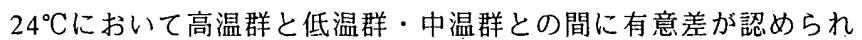
た。

\section{(4)設定気温と温冷感の関係}

図13に各設定気温における入室100～120分後の温冷感を群別の 平均值士標準偏差で示す。3群とも設定気温が低い程寒い側に、設 定気温が高い程賭い側に申告した。平均值について群別に検討する と、設定気温 $20^{\circ} \mathrm{C} \sim 28^{\circ} \mathrm{C}$ では、高温群は同じ気温を他群より、約 1 段階から2段階より寒い側に有意に評価しており、設定気温 $28^{\circ} \mathrm{C} ま$
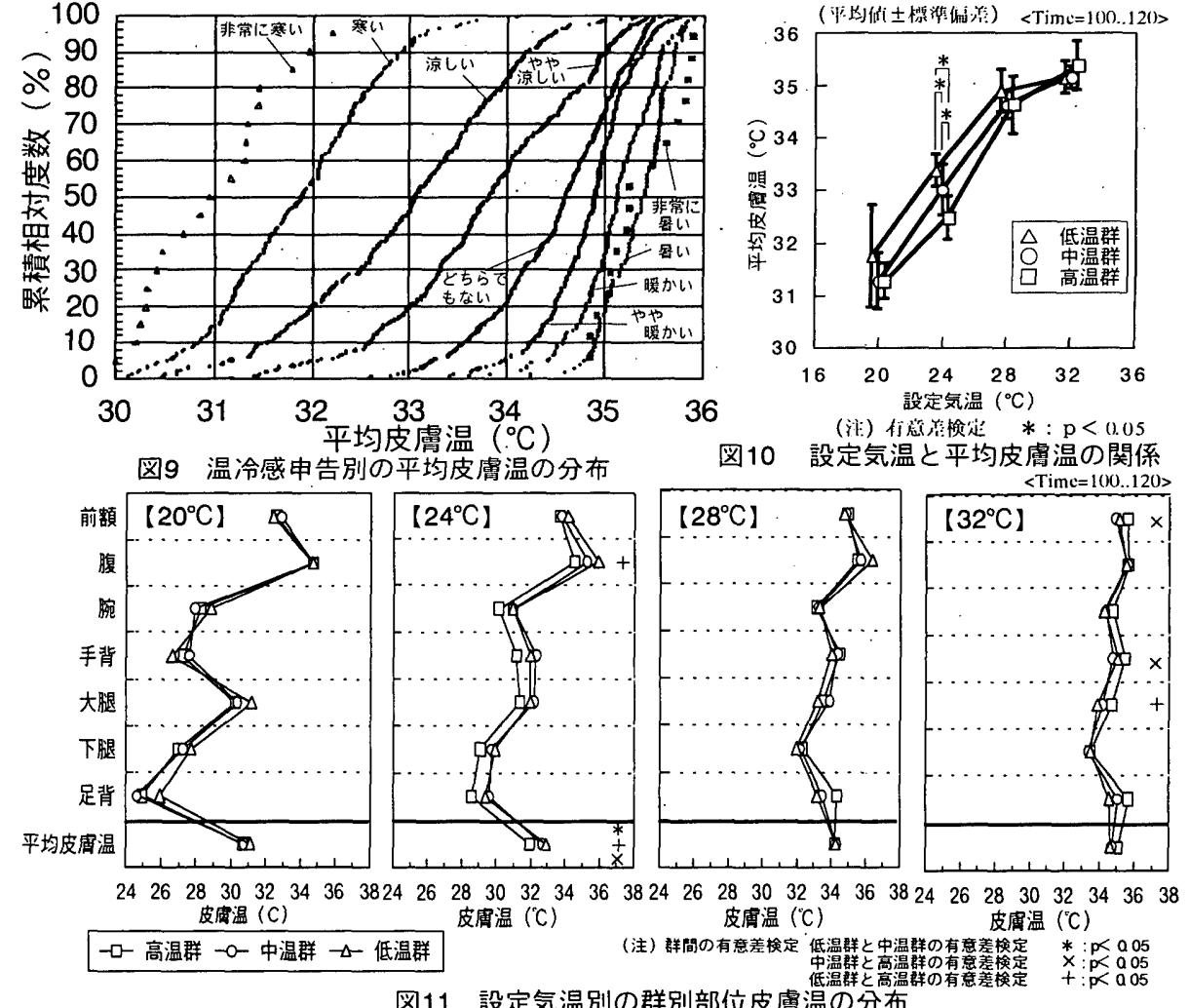

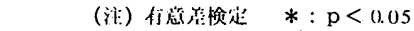

図11 設定気温別の群別部位皮膚温の分布 
で寒い側の申告であった。また、 1 段階の差は最大 $4^{\circ} \mathrm{C}$ 程度の気温

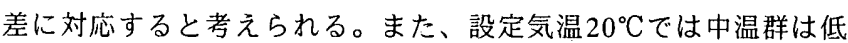
温群より約 1 段階寒い側に有意に評価したが他は低温群とほぼ同じ 評価であった。温熱的中性申告は低温群と中温群は気温 $28^{\circ} \mathrm{C}$ 近傍 で、高温群は気温 $29^{\circ} \mathrm{C}$ 近傍で認められた。また、設定気温の違い による温冷感の差は最大で低温群は4段階、中温群は4～5段階、高 温群は5〜6段階異なっており、高温群は他群より気温の違いによ る温冷感の変化が大きかった。

(5)設定気温別の部位別温冷感の関係

図14に各設定気温における入室100〜120分後の部位別温冷感を 群別の平均值で示す。部位別皮膚温の分布と同様に、3群とも各設

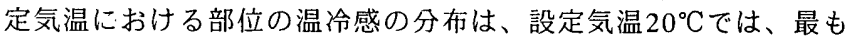
部位差が大きく、設定気温 $24^{\circ} \mathrm{C} 、 28^{\circ} \mathrm{C} 、 32^{\circ} \mathrm{C}$ になるにつれ部位差

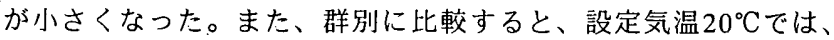
低温群は他群に比べ各部位の温冷感は約 1 段階〜2段階「どちらで もない」側であり、低温群はどの部位もあまり寒さを感じていなか

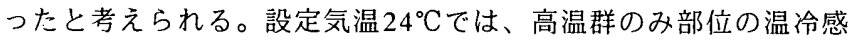
の差が大きく、また他群より約1段階〜2段階より寒い側の申告で あり、特に腕部に顕著に見られ設定気温 $20^{\circ} \mathrm{C}$ における温冷感とほ

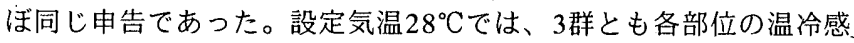
はほぼ「どちらでもない」近傍であり、群差は小さいが、「どちら でもない」を中心に高温群は涼しい側にあるのに対し、中温群と低 温群は暖かい側であり、その差は四肢末梢部において大きかった。 設定気温 $32^{\circ} \mathrm{C}$ においては、最も 3 群の申告の差が小さかった。以上 より、<暑さに対する感覚〉より<寒さに対する感覚 >が群により 異なっていた。

(6)設定気温と快適感の関係

図 15 に各設定気温における入室 100 分後〜 120 分後の快適感を群 別の平均值士標準偏差で示す。設定気温 $20^{\circ} \mathrm{C} 、 24^{\circ} \mathrm{C} 、 28^{\circ} \mathrm{C}$ で各群 に有意差が認められた。また、低温群は $20^{\circ} \mathrm{C} \sim 28^{\circ} \mathrm{C}$ 、中温群は 22 ${ }^{\circ} \mathrm{C} \sim 30^{\circ} \mathrm{C}$ 、高温群は $26^{\circ} \mathrm{C} \sim 30^{\circ} \mathrm{C}$ 範囲において快適側の申告であ り、低温群、中温群、高温群の順により高温側を快適とすると考え られる。また、最も快適と申告されると想定される気温は低温群は $24^{\circ} \mathrm{C}$ 、中温群は $24^{\circ} \mathrm{C} \sim 28^{\circ} \mathrm{C}$ の中間、高温群は $26^{\circ} \mathrm{C} \sim 28^{\circ} \mathrm{C}$ となり、 群間には $4^{\circ} \mathrm{C}$ の差が認められた。本結果と選択気温実験結果 ${ }^{6)}$ との 間に若干の差が認められたのは、設定気温評価実験ではその時の感 覚が大きく反映され、選択気温実験では、被験者の好みがより現れ るという実験方法の違いの影響によると考えられる。

(7)平均皮膚温と温冷感・快適感の関係

図 16 に入室 100 分後 120 分後の平均皮膚温と温冷感との関係を 群別に示す。平均皮䖉温が高くなると温冷感も暑い側になった。ま
た、平均皮眉温が低い方が群差が大きくなり、「-3：寒い」と感じ る皮膚温には約 $0.8^{\circ} \mathrm{C}$ 差が認められるが、平均皮瘖温が高いとほ ぼ同じであった。また、低温群、中温群は平均皮䖉温と温冷感の関 係はほぼ同じであるが、高温群は同じ皮䖉温をより涼しい側に申告 しており、温熱的中性申告は低温群、中温群は約 $33.7^{\circ} \mathrm{C}$ 、高温群は 約 $34.2^{\circ} \mathrm{C}$ で得られると考えられ、約 $0.5^{\circ} \mathrm{C}$ 差が認められた。

図17に入室 100 分後〜 120 分後の平均皮䖉温と快適感との関係を 群別に示す。快適側の申告と想定される平均皮䖉温の範囲は、低温 群は $30.2^{\circ} \mathrm{C} \sim 34.2^{\circ} \mathrm{C}$ 、中温群は $31.2^{\circ} \mathrm{C} \sim 34.4^{\circ} \mathrm{C}$ 、高温群は $31.9^{\circ} \mathrm{C} \sim$ $34.7^{\circ} \mathrm{C}$ の範囲と想定され、低温群、中温群、高温群の順に高い平均 皮膚温範囲を快適とした。これらの平均皮虚温の範囲の内、最下限 の平均皮膚温は高温群、中温群、低温群の順に低い平均皮虑温であ り、低温群と高温群には約 $1.7^{\circ} \mathrm{C}$ の差が認められた。同様に゙最上限 の平均皮膚温は低温群と高温群には約 $0.5^{\circ} \mathrm{C}$ 差が認められ、快適 と感じる最下限の皮虐温の差が大きかった。また、最も高い快適感 が得られる平均皮膚温は低温群は $32.2^{\circ} \mathrm{C}$ 、中温群は $32.8^{\circ} \mathrm{C}$ 、高温群 は33. $4^{\circ} \mathrm{C}$ と想定され、最も高い快適感が得られる平均皮膚温には約 $1.2^{\circ} \mathrm{C}$ 差が恋められ、温熱的中性申告が得られると考えられる皮 膚温の差よりも大きかった。これらの平均皮䖉温は温冷感申告で 「ゃゃ涼しい」時の各群の平均皮膚温とほぼ一致した。また、既報 6)による「ちょうど良い」,と感じる様に被験者自身が自由に調節し

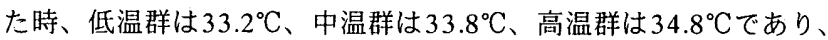
何れの群も本結果の方が約 $1^{\circ} \mathrm{C}$ 低く、特に高温群の差が大きかっ た。既往研究では、C.-E.A.Winslow ${ }^{18)}$ らは平均皮膚温 $33^{\circ} \mathrm{C}$ 付近で最 も快適とし、磯田ら ${ }^{(9)}$ は平均皮䖉温 $34^{\circ} \mathrm{C}$ 、志村 $5^{20)}$ による提案に よる至適温度状態では平 均皮膚温俚男女とも33〜 $34^{\circ} \mathrm{C}$ 範囲であることと 比較すると、快適とする 平均皮㸴温範囲は本結果 の方がやや低い側で快適 となった。榎本ら"によ る「青年に比較して同じ 気温・気流速度で高齢者 は平均皮膚温が低く、温 冷感は涼しい側、2 $3^{\circ} \mathrm{C}$ 高温側で快適感が得られ る」ことを考虑すると、 高温群は高齢者に近い生 理心理反応を示すとも考 えられる。

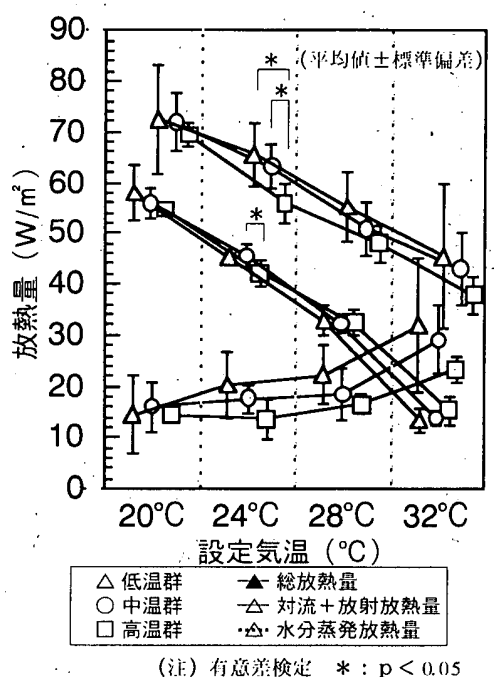

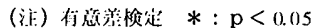

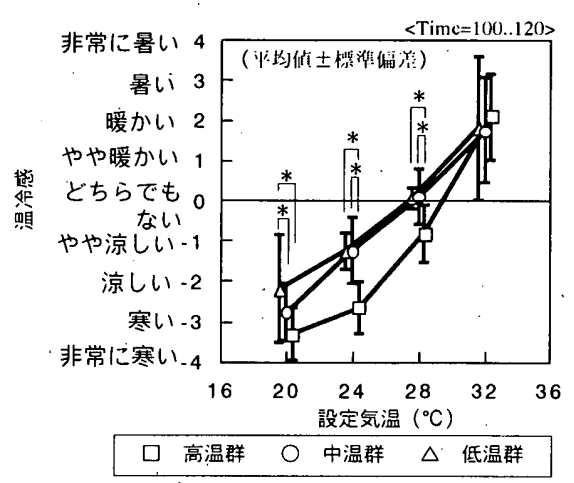

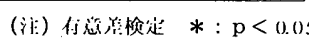

図13

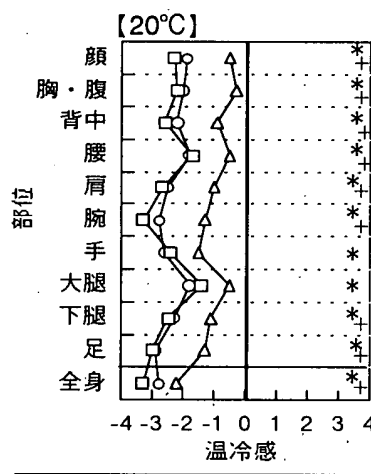

$(-4:-1$

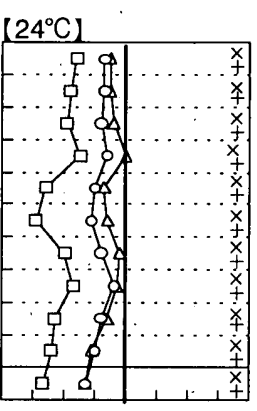

温冷感

図12 設定気温下の放熱量

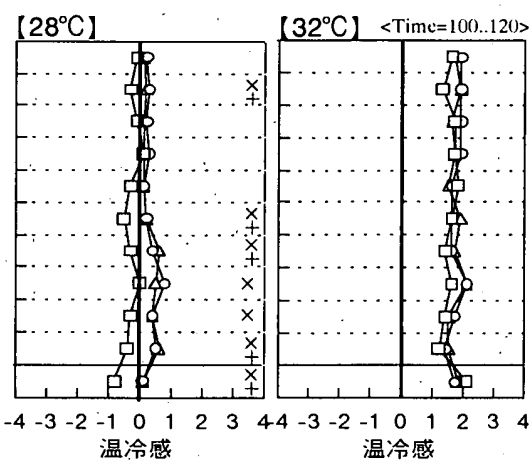

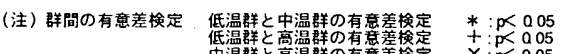
0:どちらでもない

図14 設定気温別の部位別温冷感の分布 


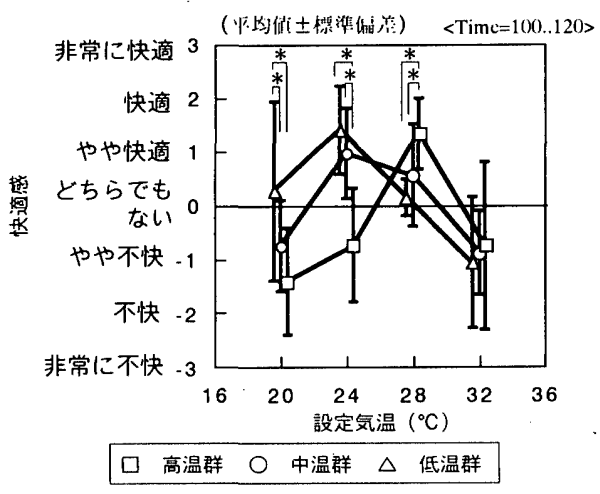

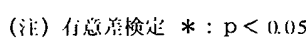

図15設定気温と快適感の関係

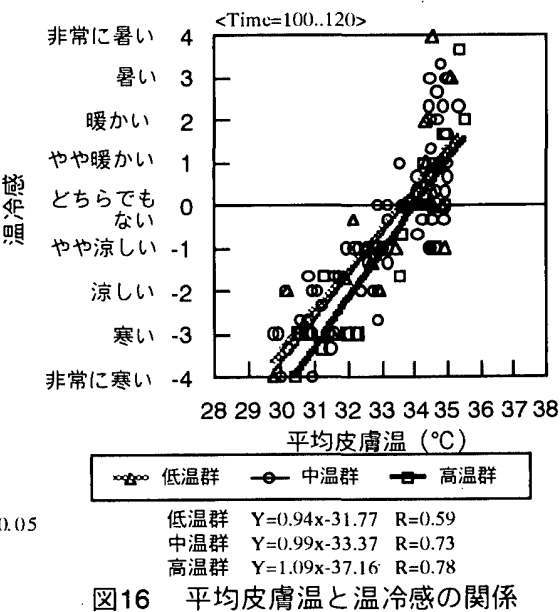

図16平均皮膚温と温冷感の関係

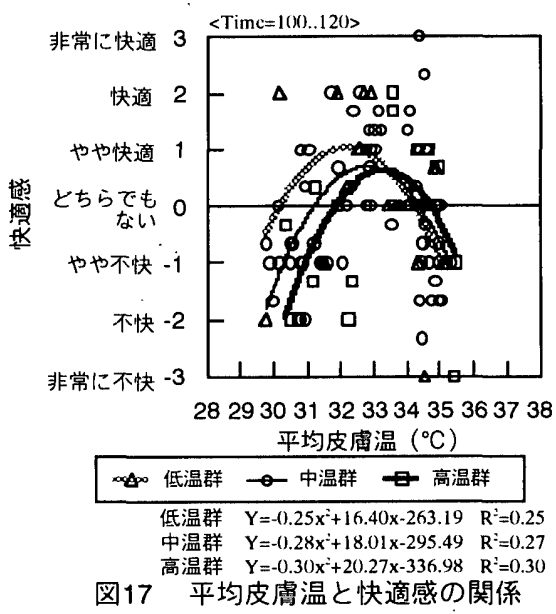

\section{5.結論}

本論文において、設定気温下に暴露する実験を行い、気温・皮䖉 温・体重減少量・温冷感・快適感などを測定し、設定気温下におけ る生理心理反応の個人差を明らかにし、それらをまとめて群別に検 討し、群別の快適性の違いについて検討した。それらの結果は以下 の様にまとめられる。

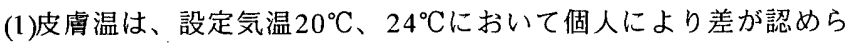
れ、特に末梢部において顕著であった。また群別には設定気温 20 ${ }^{\circ} \mathrm{C} \sim 28^{\circ} \mathrm{C}$ は低温群、中温群、高温群の順に皮膚温が低く、特に設 定気温 $24^{\circ} \mathrm{C}$ にいて有意な差が認められた。また、高温群が最も 気温の影響を受けていた。

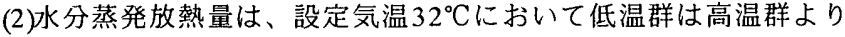
多い傾向が認められた。

(3)温冷感は、設定気温 $20^{\circ} \mathrm{C} 、 24^{\circ} \mathrm{C}$ において個人により最大で $4 \sim 5$ 段階申告が異なった。また群別には高温群は他群より同じ気温を1 段階〜2段階寒い側に有意に評価していた。

(4)快適感は、設定気温 $20^{\circ} \mathrm{C} 、 24^{\circ} \mathrm{C}$ において個人により最大で $5 \sim 6$ 段階申告が異なった。また群別には低温群、中温群、高温群の順に より高い気温範囲を快適側に評価した。

(5)同じ温冷感申告となる平均皮店温の分布は、温冷感の署い側と 寒い側では違いが見られ、寒い側で同じ温冷感となる平均皮膚温に は個人差が大きく示された。

(6)平均皮虙温と温冷感・快適感の関係は、高温群が同じ平均皮虐 温を他群より寒い側に評価し、同じ温冷感となる平均皮膚温には最 大約 $0.8^{\circ} \mathrm{C}$ の差が認められた。また、低温群、中温群、高温群の順 により高い平均皮膚温範囲を快適側に評価した。温熱的中性申告が 得られる平均皮膚温は低温群・中温群、高温群の順に高く、約 0.5 ${ }^{\circ} \mathrm{C}$ の群差が認められ、同様に最も快適が得られると考えられる平均 皮膚温も低温群、中温群、高温群の順に高く、約 $1.4^{\circ} \mathrm{C}$ の群差が認 められた。

以上より、生理心理反応に個人差が認められたが、好まれる気温 別に低温群、中温群、高温群の3群に分けることにより、その個人 差がそれぞれの特徵を持った群となった。これらの差が生じる要因 として、代謝量の違いなどについて検討し、より多くの人が快適と 感じる気温範囲の提案を行うことが今後の課題であると考えられ る。

\section{誐辞}

実験にご協力頂いた被験者の方々、当時卒論生であった門脇友美 さん、ならびに奖学寄付金を頂いた多伐工業（株）に梁謝しま す。

\section{参考文郝}

1) ASHRAE:ASHRAE Standard, Thermal Environmental Conditions for Human Occupancy,pp.5, ANSI/ASHRAE 55,1992

2) ASHRAE:1993ASHRAE HANDBOOK FUNDAMENTALS ; C hapter 8 Physiological Principles and Thermal Comfort,pp.8.18,1993

3) 樑井一夫, 斎藤純司, 後藤滋, 伊藤宏 : 標準新有効温度 (SET*) と日本人の温熱 感覚に関する実験的研究,第 報—冬季被験者実験による検討, 空気調和・衛生 工学会論文集, No 48, pp. $21 \sim 28,19922$

4) 深井一夫, 伊藤宏, 後藤滋阿久井哲斎藤純司: 標準新有効温度 (SET*) と日本 人の温熱感覚に関する実験的研究,第 2報一冬季および夏季における温熱感覚 の比較空気調和・衛生工学会論文集, No 51,pp.139 147, 1993.2

5）江口和雄, 坊垣和明 : 体感気候に関する研究, 日本建築学会大会学術講演梗概 集 (関東), pp. 353 354,昭和 50 年 10 月

6）佐々尚美, 久保博子, 磯田憲生, 梁瀬度子 : 夏期における好まれる気温の個人差 に関する研究, 日本建築学会計画系論文集, 第 531 号, pp. 31 35, 2000.5

7) N.Isoda et.al. : Performance of man-thermal environmental test system, The tenth symposium on man -thermal environment system, pp. $162 \sim 135,1986$

8）花田嘉代子, 三平和雄, 大幡久仁子 : 婦人用下着類の熱抵抗の計測に関する研 究, 織消誌 Vol. 22, Na 10 pp. 34 41, 1981

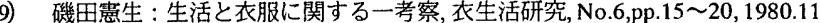

10）理科年表, 97 年度版,pp. 928

11）藏澄美仁，堀越哲美，土川忠浩，松原斎樹：日本人の体表面積に関する研究，日 本生気象学会雑誌, 第 31 巻, 第 1号, pp. 5 291994.4

12) J.D.Hardy et.al.:The technic of measuring radiation and convection , burnal of Nutrition, 15, pp.461-475, 1938

13) F.C Houghten \& C.P. Yag ou:Determining lines of equal comfort, ASHVE Trans.,(9),pp. 163-176,pp. 361-384,1923

14）久保博子, 磯田憲生,梁瀬度子 : 温冷感と快適感の季節差に関する実験的研究, 人間と生活環境第 1巻第 1号, pp..51 57,1994

15）川島美勝, 後藤滋, 大平通泰 : 住宅熱環境の調查と評価法 (4) 環境体温計の 開発と住宅熱環境法, 第 柯人間熱環境系シンポジウム報告集, pp.104〜107, 1983, 12

16) C.-E.A.Winslow,L.P.Herrington and A.P.Gagge:The determination off radiation and convection exchanges by pertitional calorimetry Am..J. Physiol. vol.116, pp.669-684,1936

17）西安信：人体と環境の熱交換温熱生理学理工学社,pp. 33 39,

18) Winslow,C.-E.A.,Herrington,L.P. and Gagge,A.P.:Temperature and Human Life, Princeton Univ.Press, 1949(北・竹村訳 ; 温度と人間、人間と技術 社、1974)

19）磯田憲生,小林陽太郎堀越哲美,池田信己：風洞内気流と人体皮浔温の関係に 関する実験的研究（着衣），中間期、暖房機および冷房機の場合-日本建築 学会論文報告集, $229, \mathrm{pp}$. 12 1 $128,1975.3$

20）志村欣一, 堀越哲美, 山岸明浩 : 日本人を対象とした室内温湿度条件の至適 域に関する実験研究 夏季至適域の提案 ; 日本建築学会計画系論文集, 第 480 号, pp. $15 \sim 24,1996.2$

21）榎本ヒカル，久保博子，磯田憲生,梁瀬度子 : 夏期における温熱環境の高秢者 への影響, 人間工学, 第 30 号特別号, pp. $280 \sim 2811994$

注 1; 本論文は 1996年度建築学会全国大会（近畿）、および第 28回熱シンボジウ ムにおいて発表したものをまとめなおしたものである。

注 2; 「対流 放射放熱量」は以下の式を用いた。また、本研究では気温と周囲壁 面温度が等しいので、To=Taとした。

$\mathrm{C}+\mathrm{R}=\mathrm{h} /(1+0.155 \mathrm{~h} \cdot \mathrm{Iclo}) \times(\mathrm{Ts}-\mathrm{To})$

$\mathrm{h}=\mathrm{hr}+\mathrm{hc}$

$$
\begin{array}{ll}
\mathrm{hr} \text { : 放射熱伝達率 }(=4.65) & \left(\mathrm{W} / \mathrm{m}^{\circ} \mathrm{C}\right) \\
\mathrm{hc} \text { : 対流熱伝達率 }(=3.7) & \left(\mathrm{W} / \mathrm{m}^{\circ} \mathrm{C}\right)
\end{array}
$$

Iclo: 衣服の熱抵抗

Ts: 平均皮膚温

To: 作用温度 ( = Ta: 気温 $\quad \rho C)$ 